\title{
ANALISIS PENYELESAIAN KREDIT BERMASALAH PADA PT. BANK PERKREDITAN RAKYAT PRIMA MULIA ANUGRAH CABANG PADANG
}

\author{
Andrika Putra, Afriyeni \\ Akademi Keuangan dan Perbankan "Pembangunan" (AKBP) Padang \\ andrikaputra02@gmail.com \\ afriyeni.yen@gmail.com
}

\begin{abstract}
The purpose of this research is to expand the insight on credit especially in terms of how the procedure settlement credit problematic conducted by PT. BPR Prima Mulia Anugrah Branch Padang. In analyzing the data, the authors use qualitative analysis method by outlining the data systematically from the facts obtained are then linked with bad debt resolution procedure on PT. BPR Prima Mulia Anugrah Branch Padang. The results of this study indicate the causes of the occurrence of bad debt caused by the bank's internal factors and influence factors of ektern (customer). Where the bank less meticulous when doing an analysis of the feasibility of a credit is given. Should the customer not deserve credit, but because of slipshod or incorrectly customer assessment into deserves credit. and from the ektern (the customer) that the existence of an economic downturn customer credit which received the customer used to develop the business and the business wound up. The completion of bad debt is done PT BPR PMA Branch Padang refers to the process of restructuring of credit in the form of rescheduling, or rescheduling, reconditioning or changes the terms of restructuring and realignment of the back.
\end{abstract}

Keyword: Non Performing Loan (NPL), Rural Bank, Bad Debt

\section{PENDAHULUAN}

Perbankan merupakan sektor terpenting dalam laju perekonomian suatu negara, sebab peningkatan ekonomi suatu negara diakibatkan oleh adanya perbankan, bahkan dalam kehidupan masyarakat sebagian besar melibatkan jasa dari perbankan. Tingkat keyakinan masyarakat terhadap perbankan terus meningkat ditandai dengan adanya peningkatan dana masyarakat kesektor perbankan.

Sejalan dengan pesatnya pembangunan di Indonesia khususnya pembangunan ekonomi, maka lembaga keuangan seperti bank adalah salah satu alat untuk membantu kelancaran ekonomi sebagai penyedia modal dalam bentuk pemberian kredit. Bank sebagai lembaga keuangan tidak pernah terlepas dari kredit sebab jumlah kredit yang diberikan akan menentukan keuntungan bank.

Menurut (Undang-Undang RI No.10 Tahun 1998) bank adalah suatu badan usaha yang menghimpun dana dari masyarakat dalam bentuk simpanan serta menyalurkannya kepada masyarakat dalam bentuk kredit dan bentuk-bentuk lainya dalam rangka meningkatkan taraf hidup hidup rakyat banyak. 
Kredit menjadi pilihan masyarakat sebagai jalan keluar untuk memenuhi kebutuhan yang terus meningkat. Disebabkan karena pendapatan yang tidak mencukupi, sehingga banyaknya penyaluran kredit yang dilakukan khususnya pada lembaga keuangan bank. Hal demikian menyebabkan kredit bermasalah cenderung naik (Olyvia, 2013). Dalam menyalurkan kredit kepada debitur, bank harus hati-hati dalam penilaian dalam meberikan kredit untuk menghindari resiko kredit bermasalah. Resiko tersebut berupa resiko tidak tertagihnya pinjaman dan terlambatnya penerimaan pinjaman darei jadwal, sehingga menimbulkan kredit macet (Afriyeni, 2009).

Setiap kredit yang diberikan tentu mengandung resiko, untuk itu bank harus merencanakan sedemikian rupa dan berusaha untuk menekan resiko munculnya kredit bermasalah. Pihak bank juga perlu menilai kelayakan usaha dari debitur dan juga diperlukan adanya pengelolaan dan pengawasan, sehingga kesinambungan usaha perbankan tetap terjaga. Penghindaran kredit bermasalah harus dilakukan supaya tidak merugikan pihak bank, sebab pendapatan terbesar bank didapat dari kegiatan penyaluran kredit (Pratiwi \& Dkk, 2016).

Kredit bermasalah adalah keadaan keuangan yang sering terjadi dilembaga keuangan terutama perbankan. Dimana pihak penerima kredit mengalami kesulitan pelunasan kredit akibat adanya kesengajaan ataupun tidaksengajaan dari debitur. Kredit yang dikatakan bermasalah belum tentu dapat dikatakan kredit macet sedangkan untuk kredit macet sudah tentu menjadi kredit bermasalah (Saputri, 2015).

Kredit yang dikembalikan tepat waktu baik itu angsuran pokok dan sekalian bunga menjadi pendapatan terbesar bagi bank, oleh sebab itu debitur harus mampu mengembalikan pinjaman beserta bunganya sesuai dengan kesepakatan yang telah disetujui di awal pemberian kredit. Akan tetapi meskipun analisis kredit telah dilakukan oleh pihak bank, pada kenyataannya ketika kredit telah diberikan timbul berbagai macam persoalan yang diakibatkan oleh faktor internal dan eksternal. Persoalan yang timbul tersebut berpengaruh terhadap tingkat pengembalian kredit sehingga dapat menyebabkan terjadinya kredit bermasalah (Ambarsita, 2013).

Bank Perkreditan Rakyat (BPR) merupakan bank yang mempunyai aktifitas usaha terbatas dengan kegiatannya meliputi penghimpunan dana dalam bentuk tabungan, deposito berjangka dan penyaluran kredit. Keterbatasan ini diberikan kepada BPR terkait dengan tujuan pelayanan utama BPR kepada usaha mikro kecil dan menengah serta masayarakat sekitar (Saputri, 2015).

PT. Bank Perkreditan Rakyat (BPR) Prima Mulia Anugrah Cabang Padang merupakan salah satu BPR yang masih aktif beroperasi di kota Padang, yang memberikan pelayanan jasa kepada masyarakat dalam berbagai bentuk. Salah satu pelayanan yang disalurkan bank tersebut adalah dalam bentuk pemberian fasilitas kredit. Peningkatan pemberian kredit oleh bank dapat mengakibatkan laba yaitu berupa bunga atas pinjaman yang diberikan kepada nasabah dan juga akan menaikkan jumlah piutang pada bank tersebut. Dengan naiknya jumlah kredit akan diikuti pula oleh kemungkinan tidak tidak tertagihnya kredit dan terjerat kedalam kredit bermasalah. 
Kolektibilitas kredit pada PT. Bank Perkreditan Rakyat Prima Mulia Anugrah Cabang Padang empat tahun terakhir yang dapat dilihat pada tabel dibawah ini :

Tabel 1

Kolektibilitas Kredit

Bank Perkreditan Rakyat Prima Mulia Anugrah Cabang Padang

Periode 2015-2018

(Dalam Rupiah)

\begin{tabular}{|l|l|l|l|l|l|}
\hline \multirow{2}{*}{ Tahun } & \multicolumn{4}{|c|}{ Kolektibilitas } & \multirow{2}{*}{ Total kredit } \\
\cline { 2 - 6 } & Lancar & Kurang Lancar & Diragukan & Macet & \\
\hline 2015 & 3.326 .117 .901 & 132.716 .667 & 204.656 .662 & 135.342 .407 & 3.798 .833 .637 \\
\hline 2016 & 2.741 .016 .561 & 27.333 .331 & 128.784 .231 & 614.765 .597 & 3.511 .889 .720 \\
\hline 2017 & 3.156 .716 .632 & & 8.344 .444 & 613.464 .934 & 3.778 .526 .010 \\
\hline 2018 & 8.987 .977 .896 & 19.444 .449 & 226.333 .330 & 511.673 .709 & 9.745 .429 .384 \\
\hline
\end{tabular}

Sumber : PT. BPR PMA Cabang Padang.

Berdasarkan tabel tersebut bisa dilihat kredit bermasalah selama empat tahun pada PT. BPR Prima Mulia Anugrah Cabang Padang berdasarkan kolektibilitas kredit yaitu tergolong bermasalah yang dilihat dari kualitas kurang lancar, diragukan dan macet dibandingkan dengan kredit yang tergolong lancar. Berdasarkan uraian diatas penulis tertarik untuk menganalisa masalah tersebut dengan judul "Analisis Penyelesaian Kredit Bermasalah Pada PT. BPR Prima Mulia Anugrah Cabang Padang"

\section{TINJAUAN PUSTAKA}

\section{Pengertian Bank}

Pada mulanya bank sebenarnya tidak asing bagi kita, khususnya yang berada di perkotaan bahkan didesa-desa sekalipun, pada saat ini bank suatu kata yang tidak asing dan aneh lagi. Terdengar kata saja kata bank orang selalu teringat dengan uang, disebabkan bank bergerak dibidang keuangan. Seperti bagi negaranegara maju, bank menjadi bagian terpenting bagi masyarakat dalam kebutuhan bertransaksi.

Bank merupakan suatu lembaga keuangan yang mempunyai peranan penting bagi kegiatan perekonomian, yaitu upaya mencapai tujuan pembangunan yang dilakukan, baik itu kebijakan fisikal maupun kebijakan moneter (Hefrimal \& Afriyeni, 2013).

Menurut Pratiwi \& Dkk, (2016). bank disebut sebagai lembaga perantara keuangan karena bank mempermudah proses pengalihan dana dari pihak yang kelebihan dana kepihak yang kekurangan dana atau membutuhkan dana.

\section{Pengertian Bank Perkreditan Rakyat}

Bank Perkreditan Rakyat menerima simpanan hanya dalam bentuk deposito berjangka, tabungan, dan atau bentuk lainnya yang dipersamakan dengan itu. Tugas pokok BPR diarahkan untuk menunjang pertumbuhan ekonomi masyarakat, dengan semakin banyaknya kebutuhan masyarakat BPR bertujuan memberikan jasa kepada masyarakat pedesaan dan masyarakat golongan ekonomi lemah di daerah perkotaan (Debby \& Elim, 2015). 


\section{Pengertian Kredit}

Menurut Mulyaningrum, (2016) Kredit adalah pinjaman yang wajib dikembalikan beserta bunganya oleh peminjam sesuai dengan perjanjian yang telah ditetapkan diawal. Kredit juga merupakan kemampuan seseorang atau badan usaha untuk menggunakan uang, barang atau jasa yang diterimanya dihubungkan dengan kemampuan untuk mengembalikan setelah jangka waktu yang telah ditentukan.

Menurut Rangkuti, (2018) kredit yaitu bisnis yang berisiko, dimana ada kemungkinan kredit yang diberikan tidak dapat ditagih. Debitur dapat menyebutkan banyak alasan untuk tidak membayar kewajibannya. Disisi lain bank harus membayar setiap rupiah dana nasabah yang ditempatkan padanya. dan menurut Soedarsa \& Raharjo, (2015) dalam menyalurkan kredit kepada masyarakat tidak keseluruhan dana yang telah disalurkan tersebut dapat dikembalikan, maka hal demikian penyebab timbulnya kredit bermasalah. Apabila terjadi peningkatan terhadap kredit bermasalah, maka secara tidak langsung akan menghambat terbentuknya pendapatan bunga yang seharusnya diterima dan akan mengganggu kegiatan operasional pada perbankan.

\section{Fungsi dan Tujuan Penyaluran Kredit}

Widya (2016), menyatakan kredit berfungsi memajukan arus tukar-menukar barang atau jasa, menciptakan alat pembayaran baru, mengaktifkan serta meningkatkan manfaat potensi ekonomi yang ada, sedangkan tujuan penyaluran kredit yaitu untuk mendapatkan keuntungan, sehingga maasyarakat yang meminjam dana dapat memperoleh simpanan beserta bunganya tanpa adanya kekhawatiran kredit yang bermasalah.

Pemberian kredit bertujuan untuk mencari keuntungan bagi bank dengan memanfaatkan bunga, bentuk bunga bank yang diterimanya sebagai balas jasa dan biaya administrasi yang dibebankan kepada debitur dan membantu mengembangkan usaha debitur. Selain tujuan yang dilakukan dalam pemberian fasilitas kredit, bank juga berfungsi dalam memberikan kreditnya kepada nasabah diantaranya untuk meningkatkan daya guna uang (Nazila \& Dkk, 2016).

Dari definisi diatas, maka bank mempunyai peranan yang penting dalam perekonomian, khususnya dibidang Moneter karena dapat menunjang pembangunan ekonomi.

\section{Pengertian Kredit Bermasalah}

Kredit bermasalah yaitu gambaran dari situasi, persetujuan dan pengembalian kredit yang mengalami resiko kegagalan bahkan, cenderung mengalami kerugian. dan keadaan dimana debitur tidak sanggup membayar sebagian atau seluruh kewajibanya kepada bank sesuai jangka waktu yang sudah ditentukan.

Kredit bermasalah adalah kredit yang diberikan pihak bank kepada nasabah dimana nasabah tidak melakukan pembayaran atau melakukan angsuran sesuai dengan perjanjian yang telah ditanda tangani oleh bank dan nasabah (Wahyuni \& Shahfithrah, 2018).

\section{Kolektibilitas Kredit}

Kolektibilitas kredit yaitu suatu keadaan yang mencerminkan mengenai pembayaran pokok atau angsuran pokok dan bunga kredit yang dilakukan nasabah 
dan tingkat kemungkinan diterimanya kembali kredit yang diberikan kepada debitur (Lailiyah, 2014).

Kolektibilitas kredit dapat dibedakan atas lima jenis yaitu:

1. Lancar, yaitu kredit tanpa tunggakan

2. Dalam Perhatian Khusus, yaitu kredit yang mempunyai tunggakan pokok atau bunga $1 \mathrm{~s} / \mathrm{d} 90$ hari

3. Diragukan, yaitu kredit yang mempunyai tunggakan pokok atau bunga $91 \mathrm{~s} / \mathrm{d}$ 180 hari

4. Diragukan, yaitu kredit yang mempunyai tunggakan pokok atau bunga $181 \mathrm{~s} / \mathrm{d}$ 270 hari

5. Macet, yaitu kredit yang mempunyai tunggakan pokok atau bunga lebih dari 270 hari.

\section{METODE PENELITIAN}

Metode penelitian yang digunakan metode analisa kualitatif yaitu dengan menguraikan data secara sistematis dari fakta-fakta yang didapat kemudian dihubungkan dengan prosedur penyelelsaian kredit bermasalah pada PT. Bank Perkreditan Rakyat Prima Mulia Anugrah Cabang Padang.

\section{HASIL DAN PEMBAHASAN}

\section{Proses Dalam Pemberian Kredit}

Proses pemberian kredit pada BPR Prima Mulia Anugrah Cabang Padang dimulai dari penerimaan permohonan kredit yang diajukan calon debitur. Permohonan kredit harus diajukan secara tertulis dengan menggunakan format yang telah ditentukan oleh BPR PMA Cabang Padang yang isinya memuat informasi lengkap mengenai kondisi pemohon kredit. Biasanya permohonan tersebut berisi tentang nama pemohon, alamat pemohon, nama perusahaan, alamat perusahaan, jumlah permohonan pinjaman, jangka waktu kredit, rencana penggunaan pinjaman, agunan yang diserahkan sebagai jaminan kredit, izin-izin usaha yang dimiliki debitur termasuk riwayat kreditnya pada bank lain (kalau ada).

Atas permohonan pinjaman kredit yang diajukan debitur tersebut, BPR PMA Cabang Padang akan melakukan penelitian apakah permohonan tersebut diterima atau ditolak dan apakah nasabah tersebut termasuk kedalam kelompok nasabah yang dapat dilayani atau tidak. Apabila calon nasabah tersebut diluar kriteria yang ditentukan oleh bank, maka permohonan langsung ditolak. Sedangkan apabila termasuk dalam kriteria yang dapat dilayani maka permohonan tersebut akan diregistrasi dalam buku yang telah ditetapkan untuk itu, yang kemudian di disposisikan oleh pimpinan kepala cabang sesuai dengan wewenang yang dimilikinya. Hasil dari disposisi tersebut akan didistribusikan kepada analis kredit yang berwenang atau yang bertugas memproses permohonan kredit dari calon debitur.

\section{Penyebab Kredit Bermasalah}

Menurut Sjafitri, (2011) timbulnya kredit bermasalah disebabkan oleh 3 faktor yaitu : 
1. Faktor intern bank, yaitu analisis kredit yang kurang mampu atau disebabkan pimpinan yang mendapat tekanan dari pihak luar, pimpinan bank yang terlalu agresif dalam menyalurkan kredit dan adanya campur tangan dari para pemegang saham.

2. Ketidaklayakan debitur, yaitu debitur menderita sakit berat, kecelakaan atau meninggal dunia dan penghasilan tetap tertanggu.

3. Pengaruh faktor ektern, yaitu penurunan kondisi ekonomi, Bencana alam dan peraturan pemerintah.

Pada PT. BPR Prima Mulia Anugrah Cabang Padang terjadinya kredit bermasalah disebabkan oleh faktor intern bank dan pengaruh faktor ektern (nasabah). Dimana pihak bank kurang teliti dalam melakukan analisis terhadap kelayakan suatu kredit yang akan diberikan kepada debitur. Dimana pihak debitur tidak layak untuk menerima kredit, namun karena salah penilaian dari pihak bank terhadap nasabah tersebut sehingga kredit diberikan kepada debitur. dan dari pihak ektern (nasabah) yaitu adanya penurunan ekonomi nasabah yang mana kredit yang diterima nasabah digunakan untuk mengembangkan usaha dan usaha tersebut mengalami kegagalan. Contohnya persaingan bisnis yang ketat menyebabkan berkurangnya pendapatan pada usaha nasabah, sehingga nasabah tidak mampu membayar kreditnya.

Sebelum Penulis melanjutkan tentang penyelesaian kredit bermasalah, terlebih dahulu ada baiknya di lihat Perhitungan Non Performing Loan (NPL) pada PT. BPR Prima Mulia Anugrah Cabang Padang berdasarkan pada tabel 1.1 sbb:

Tahun 2015

$$
\begin{aligned}
\text { NPL } & =\frac{\text { Total Non Performing Loan }}{\text { Total Kredit }} \times 100 \% \\
& =\frac{472.715 .736}{3.798 .833 .637} \times 100 \% \\
& =12,44 \%
\end{aligned}
$$

Tahun 2016

$$
\begin{aligned}
\text { NPL } & =\frac{\text { Total Non Performing Loan }}{\text { Total Kredit }} \times 100 \% \\
& =\frac{770.883 .159}{3.511 .889 .720} \times 100 \% \\
& =21,95 \%
\end{aligned}
$$

Tahun 2017

NPL $=\frac{\text { Total Non Performing Loan }}{\text { Total Kredit }} \times 100 \%$

$$
\begin{aligned}
& =\frac{621.809 .378}{3.778 .526 .101} \times 100 \% \\
& =16,46 \%
\end{aligned}
$$

Tahun 2018

$$
\begin{aligned}
\text { NPL } & =\frac{\text { Total Non Performing Loan }}{\text { Total Kredit }} \times 100 \% \\
& =\frac{757.451 .488}{9.745 .429 .384} \times 100 \% \\
& =7,77 \%
\end{aligned}
$$


Tabel 2

Perhitungan Non Performing Loan (NPL)

Bank Perkreditan Rakyat Prima Mulia Anugrah Cabang Padang Periode 2015-2018

\begin{tabular}{|c|c|c|c|}
\hline Tahun & Jumlah NPL & Total Kredit & NPL \\
\hline 2015 & Rp. 472.715.736 & Rp. 3.798.833.637 & $12,44 \%$ \\
\hline 2016 & Rp. 770.883.159 & Rp. 3.511.889.720 & $21,95 \%$ \\
\hline 2017 & Rp. 621.809.378 & Rp. 3.778.526.010 & $16,46 \%$ \\
\hline 2018 & Rp. 757.451.488 & Rp. 9.745.429.384 & $7,77 \%$ \\
\hline
\end{tabular}

Sumber : BPR PMA Cabang Padang

Berdasarkan tabel perhitungan Non Performing Loan (NPL) di atas dapat diketahui PT. BPR PMA Cabang Padang mengalami penurunan dan kenaikan terhadap kredit bermasalahnya, pada tahun 2015 menunjukkan tingkat Non Performing Loan (NPL) sebesar 12,22\% kemudian mengalami kenaikan yang sangat tinggi pada tahun 2016 yaitu NPL nya sebesar $21,95 \%$ dan pada tahun 2017 kredit bermasalah mengalami penurunan sebesar 5,49\% menjadi 16,46\% kemudian mengalami penurunan kembali pada tahun 2018 sebesar 8,69\% menjadi 7,77\%. Artinya Non Performing Loan (NPL) PT. BPR PMA Cabang Padang dari tahun 2015-2018 secara keseluruhan masih berada diatas 5\% meskipun adanya penurunan NPL dari tahun 2017-2018 namun NPL tersebut masih melebihi ketentuan yang ditetapkan oleh Bank Indonesia. Kredit bermasalah yang terdiri dari kredit kurang lancar, kredit diragukan dan kredit macet cenderung mengalami penurunan sejak tahun 2016 hingga 2018. Kredit bermasalah tertinggi berada pada tahun 2016 dan terjadi penurunan hingga tahun 2018, keadaan ini menunjukkan manajemen kredit yang baik telah dilakukan PT. BPR PMA Cabang Padang. Seluruh jumlah kredit yang telah disalurkan kepada debitur menjadi pendapatan terbesar bagi PT. BPR Prima Mulia Anugrah Cabang Padang. Seluruh debitur diharapkan mampu mengembalikan pinjaman beserta bunganyanya sesuai dengan kesepakatan yang telah disetujui bersama.

\section{Dampak Penyebab Kredit Bermasalah}

Secara umum kredit bermasalah yaitu kredit yang dapat menimbulkan persoalan terhadap bank selaku lembaga pemberi kredit dan juga terhadap debitur. Beberapa dampak yang diakibatkan oleh kredit bermasalah adalah sebagai berikut:

1. Terhadap Bank
a. Menggangu kinerja dari staf PT. BPR PMA Cabang Padang
b. Adanya biaya tambahan yang harus dikeluarkan.
c. Keuntungan bank berkurang
d. Modal bank terancam tidak berkembang
e. Dan lain-lain.

2. Terhadap Nasabah
a. Nama baik nasabah menjadi buruk dikalangan perbankan dan dunia bisnisnya. Apalagi jika sudah menjadi kredit macet maka akan masuk Daftar Hitam Bank Indonesia.


b. Nasabah harus mengeluarkan biaya khusus seperti : biaya bunga dan dendanya, biaya pengacara jika sudah memasuki jalur hukum, biaya waktu dan tenaga yang sulit diukur.

c. Hilangnya berbagai mungkin kesempatan yang harus diperoleh.

d. Hilangnya kepercayaan pihak bank.

\section{Penyelesaian Kredit Bermasalah}

Sebagai salah satu kegiatan Bank yang mengandung risiko tinggi maka sedapat mungkin dilakukan upaya-upaya pencegahan timbulnya risiko/ kredit bermasalah dikemudian hari, diantaranya melalui proses pemberian kredit menggunakan prinsip kehati-hatian serta berpedoman pada tatacara pemberian kredit yang sehat.

Penyelamatan kredit bermasalah selalu dilakukan oleh setiap bank untuk mendapatkan cara agar dapat menyelesaikan kredit yang bermasalah pada bank, semua dilakukan guna menjadi kinerja usaha yang dijalankan oleh bank agar lebih efektif dan efisien sehingga bank dapat menjalankan kegiatannya dengan baik, semakin baik strategi yang digunakan maka akan mengakibatkan semakin rendahnya rasio Non Performing Loan (Fitria \& Sari, 2012).

PT. BPR PMA Cabang Padang menempuh langkah penyelesaian kredit bermasalah sebagai berikut:

1. Penjadwalan kembali (Rescheduling), adalah nasabah masih mempunyai itikad dan keinginan untuk membayar, maka pihak bank melakukan dengan cara penjadwalan kembali dan langkah-langkah penyelesaiannya adalah:

a. Memberikan perpanjangan jangka waktu kredit, yaitu nasabah diberikan keringanan dalam masalah waktu pelunasan.

b. Memperpanjang jangka waktu angsuran, hampir sama dengan jangka waktu kredit yaitu jangka waktu angsuran kreditnya diberi perpanjangan.

c. Perubahan jumlah angsuran, yaitu memberikan perubahan jumlah angsuran ini dilihat atas dasar kemampuan nasabah mengingat kreditnya yang bermasalah, maka pihak bank memberikan kemudahan dengan memperkecil jumlah angsuran pokok.

2. Persyaratan kembali (Reconditioning), merupakan penyelamatan dengan cara perubahan syarat kredit antara lain :

a. Penurunan tingkat suku bunga agar meringankan nasabah.

b. Pembayaran bunga ditunda sampai waktu ketetapan, tetapi pokok pinjaman tetap dibayar seperti biasa, sedangkan bunganya bisa ditunda pembayarannya.

3. Penataan kembali (Restrukturing), yaitu perubahan persyaratan kredit yang menyangkut penambahan fasilitas kredit dan konversi seluruh atau sebagian tunggakan angsuran bunga menjadi pokok kredit baru yang dapat disertai dengan penjadwalan kembali dan/atau persyaratan kembali. 


\section{SIMPULAN}

Berdasarkan uraian yang telah dikemukakan, maka dapat ditarik kesimpulan sebagai berikut :

1. Bank Perkreditan Rakyat (BPR) Prima Mulia Anugrah Cabang Padang (PMA) merupakan bank yang menghimpun dana dari masyarakat dan memberikan pinjaman dalam bentuk kredit yang tujuannya adalah untuk membantu masyarakat yang kekurangan dana.

2. Kredit bermasalah yang terdiri dari kredit kurang lancar, kredit diragukan dan kredit macet cenderung mengalami penurunan sejak tahun 2016 hingga 2018. Kredit bermasalah tertinggi berada pada tahun 2016 dan terjadi penurunan hingga tahun 2018, keadaan ini menunjukkan manajemen kredit yang baik telah dilakukan PT. BPR PMA Cabang Padang.

3. Penyebab kredit bermasalah pada PT. BPR PMA Cabang Padang karna kesalahan pihak bank yang kurang teliti ketika melakukan analisis terhadap kelayakan suatu kredit yang diberikan dan kesalahan dari pihak nasabah yang diakibatkan adanya penurunan ekonomi seperti kegagalan dalam bidang usaha.

4. Penyelesaian kredit bermasalah yang dilakukan PT. BPR PMA Cabang Padang mengacu pada proses restrukturisasi kredit berupa rescheduling, atau penjadwalan ulang, reconditioning atau perubahan persyaratan kembali dan restructuring penataan kembali.

\section{UCAPAN TERIMA KASIH}

Terimakasih penulis sampaikan kepada :

1. Kedua orang tua yang selalu memberikan dukungan baik itu secara moril mapun materil.

2. Direktur AKBP dan prodi AKBP yang memberikan kesempatan kepada penulis untuk melakukan penelitian ini.

3. Dosen Pembimbing tugas akhir yang selalu memberikan arahan dan bimbingan sampai tugas akhir ini bisa tersiapkan.

4. Kepala cabang PT. BPR Prima Mulia Anugrah Cabang Padang yang telah mengizinkan penulis dalam memperoleh informasi beserta pengambilan data.

5. Semua pihak yang sudah membantu dan memberikan dukungan dalam penyelesaian tugas akhir.

\section{DAFTAR PUSTAKA}

Afriyeni, A. (2009). Analisis Pengaruh Pemberian Kredit Terhadap Profitabilitas PT. Bank Pembangunan Daerah (BPD) Sumatera Barat. Jurnal KBP, 1(2), 113.

Afriyeni, A., \& Putra, Y. E. (2019). Analisis Faktor-Faktor Yang Mempengaruhi Tingkat Pengembalian Kredit Usaha Rakyat (KUR) PT. Bank Rakyat Indonesia (BRI) Unit Talang Cabang Solok. https://doi.org/10.31219/osf.io/crfpg 
Amelia, L., \& Marlius, D. (2018). Pengendalian Kredit Dalam Upaya Menciptakan Bank Yang Sehat Pada PT. Bank Pembangunan Daerah Sumatera Barat Cabang Utama Padang. https://doi.org/10.31227/osf.io/kpc64

Alanshari, F., \& Marlius, D. (2018). Prosedur Pemberian Kredit KPR Pada PT. Bank Tabungan Negara (Persero) TBK Cabang Pembantu Bukittinggi. https://doi.org/10.31227/osf.io/rsfhc

Ambarsita, L. (2013). Analisis Penanganan Kredit Macet. Jurnal Manajemen Bisnis, 3(1), 1-7.

Debby, E. N., \& Elim, I. (2015). Analisis Laporan Keuangan Dalam Mendukung Keputusan Pemberian Kredit Pada PT. Bank Perkreditan Rakyat Nusa Utara. Jurna Emba, 3(2), 326-335.

Febriansyah, I., \& Afriyeni, A. (2019). Penyelesaian Kredit Bermasalah PT. Bank Pembangunan Daerah (BPD) Sumbar Cabang Alahan Panjang Kabupaten Solok. https://doi.org/10.31219/osf.io/vutmj

Fitria, N., \& Sari, L. (2012). Analisis Kebijakan Pemberian Kredit dan Pengaruh Non Performing Loan Terhadap Loan To Deposit pada PT. Bank Rakyat Indonesia (Persero), Tbk Cabang Rantau, Aceh Tamiang. (Periode 200720011). Jurnal Ekonomi Dan Keuangan, 1(1), 88-101.

Hefrimal, J. P., \& Afriyeni. (2013). Pengawasan Kredit PT. Bank Perkreditan Rakyat Koto Sebelas Tarusan. Akademi Keuangan Dan Perbankan, 1-16.

Lailiyah, A. (2014). Urgensi Analisa 5c Pada Pemberian Kredit Perbankan Untuk Meminimalisir Resiko, 29(2), 217-232.

Mulyaningrum, M. D. (2016). Kredit Bermasalah di Bidang Kredit Modal Kerja ( Studi pada PT Bank Rakyat Indonesia ( Persero ) Tbk . Cabang Jombang ). Administrasi Bisnis, 32(1), 121-127.

Nazila, L. R., \& Dkk. (2016). Analisis Penyelesaian Kredit Bermasalah Atas Agunan Harta Tidak Bergerak (Studi pada PT Bank Mandiri Tbk. unit Mikro Cabang Kraksaan). Jurnal Administrasi Bisnis, 33(1), 78-85.

Olyvia, D. (2013). Faktor Faktor Penyebab Kredit Bermasalah di PT. Bank Sulut Cabang Utama Manando. Jurnal EMBA, 1(4), 69-77.

Orlando, A., \& Susanto, R. (2019). Mekanisme Pencairan Kredit Usaha Rakyat Pada PT. Bank Rakyat Indonesia Unit Lubuk Buaya. https://doi.org/10.31219/osf.io/zuv2y 
Pratama, D., \& Fernos, J. (2019). Prosedur Pelaksanaan Kredit Usaha Rakyat (KUR) Pada PT. Bank Nagari Cabang Padang. https://doi.org/10.31227/osf.io/ag68j

Pratiwi, Y. W., \& Dkk. (2016). Analisis Manajemen Risiko Kredit Untuk Meminimalisirkan Kredit Modal Kerja Bermasalah (Studi Kasus PT. Bank Rakyat Indonesia (persero), Tbk Cabang Ponorogo). Jurnal Administrasi Bisnis, 38(1), 157-163.

Rangkuti, T. (2018). Pengaruh Analisis Kredit Terhadap Pembiayaan Bermasalah (Kredit Macet) Pada PT. Bank Pembiayaan Rakyat Syariah Artha Madani Cikarang, Jawa Barat. Jurnal Transparansi, 1(1), 68-84.

Saputri, R. (2015). Analisis Penyelesaian Kredit Bermasalah Pada PD. BPR Samaridu Cabang Pekanbaru. Jom FISIP, 2(2), 1-10.

Sjafitri, H. (2011). Faktor-Faktor Yang Mempengaruhi Kualitas Kredit Dalam Dunia Perbankan. Jurnal Manajemen Dan Kewirausahaan, 2(2), 106-120.

Soedarsa, H. G., \& Raharjo, A. I. (2015). Analisi Kredit Berasalah Dan Penghapusan Kredit Bermasalah Terhadap Penigkatan Net Prpfit Margin (Studi Kasus Pada PT. Bank Rakyat Indonesia (Persero), Tbk Tahun 20112013). Jurnal Akuntansi \& Keuangan, 6(2), 125-135.

Undang-Undang RI NO.10 Tahun 1998. (n.d.). Undang-Undang Republik Indonesia Nomor 10 Tahun 1998 Tentang Perubahan Atas Undang-Undang Nomor 71992 Tentang Perbankan.

Wahyuni, A. L., \& Shahfithrah, S. (2018). Strategi Bank BRI Syariah Dalam Menangani Kredit Bermasalah di BRI Syariah KC. Medan. Jurnal Agama Dan Pendidikan Islam, 9950(June), 1-18.

Widayati, R. (2019). Penyelesaian Kredit Bermasalah Pada PT. Bank Perkreditan Rakyat (BPR) Nagari Kasang. https://doi.org/10.17605/OSF.IO/D4MF3

Widayati, R. (2019). Pelaksanaan Prinsip Kehati-Hatian Dalam Pemberian Kredit Konsumtif Pada Bank Nagari Cabang Siteba. https://doi.org/10.17605/OSF.IO/FZVXR

Widayati, R. (2019). Aktivitas Pemberian Kredit Komersil Pada Bank Nagari Cabang Sijunjung. https://doi.org/10.17605/OSF.IO/QTVZ9

Yasman, R., \& Afriyeni, A. (2019). Prosedur Pemberian Kredit Pada PT. Bank Pekreditan Rakyat (BPR) Jorong Kampung Tangah (JKT) Pariaman Cabang Padang. https://doi.org/10.31219/osf.io/c5ufr 